doi: 10.52370/TISC21145DG

\title{
THE ROLE OF TRAVEL HEALTH INSURANCE IN TOURISM DEVELOPMENT - CHALLENGES AND PERSPECTIVES
}

\author{
Danijela Glušac ${ }^{l}$
}

\begin{abstract}
Travel health insurance is insurance for travellers during their travel and stay in a foreign country in case of necessary assistance in connection with the arrangement and provision of necessary treatment, transport to the medical institution or country of residence, due to sudden illness or injury of the insured. The onset of the COVID-19 pandemic mainly affected this area of insurance, and therefore, insurers were presented with challenges. The need for research on travel health insurance can be seen in the complexity of the relationships, types and modalities. The author analyses the essential characteristics of this type of insurance, indicating the legislative framework and contract regulation in general and special conditions of insurers. This paper aims at contributing to research of travel health insurance. This study will significantly to the limited literature on travel health insurance, and it will have an implication on the insurance sector for further diversification of their products.
\end{abstract}

Key Words: insurance, tourism, travel health insurance, contract JEL classifiction: $G 22, K 12$

\section{Introduction}

Travel health insurance protects in the case of an emergency illness and injury during a stay abroad. Travel health insurance is a travel insurance for the time of travel and stay abroad in case of necessary assistance in connection with: the arrangement and provision of necessary treatment, transportation to a health facility or country of residence, which is the result of a sudden illness or injury of the insured. As a complex activity, insurance

\footnotetext{
${ }^{1}$ Danijela Glušac, Research associate, Faculty of Law, University of Kragujevac, Jovana Cvijića 1, Phd student, Faculty of Law, University of Novi Sad, Trg Dositeja Obradovića 1, +381643829750, danijela.vps@gmail.com
} 
provides financial protection of property and persons from risk, i.e. damage, and eliminated or reduced harmful effects (Glušac, 2020). Numerous changes have affected the insurance market of the Republic of Serbia, but it is non-life insurance and thus travel insurance, that recorded an increase from year to year (until 2020). Today's lifestyle and frequent business and private trips have led to the need to contract travel insurance. This form of insurance has characteristics of health insurance and accident insurance. According to the annual reports published by the National Bank of Serbia, the total premium for travel health insurance in 2019 was 390,310,000 RSD, and in 2018 it was 41,813,000 RSD (National Bank of Serbia, 2018, 2019).

\section{Legal aspect of travel health insurance}

Travel health insurance is the insurance for travellers during their travel and stay in a foreign country in case of the necessary assistance in connection with: the arrangement and provision of necessary treatment, transport to the medical institution or country of residence, due to sudden illness or injury of the insured. Travel health insurance covers different risks from various hazards. Coverage refers to health insurance, travel assistance and legal assistance. This insurance covers the risks and dangers for persons, physical integrity, physical ability, etc., at a particular time or for a certain period (Vojinović \& Glavaš, 2019). The term for this type of insurance which can be found in the terms and conditions of Serbian insurance companies is insurance for travellers during their travel and stay in a foreign country. This type of insurance is not explicitly regulated by law, except for one article in the Law on Health Insurance ("Official Gazette of the Republic of Serbia", No. 25/2019), but these detailed provisions can be found in the terms and conditions of insurance companies. All provisions governing the insurance contract apply to this type of insurance: the Law of Contract and Torts ("Official Gazette of the SFR of Yugoslavia No. 29/1978; Amendments Nos: 39/1985, 45/1989, and 57/1989; final amendments in the Official Gazette of the FR of Yugoslavia, No. 31/1993") and the Insurance Law ("Official Gazette of the Republic of Serbia", No. 139/2014) and other regulations. Travel insurance is a type of voluntary health insurance that contracts for the use of health care of insured persons of voluntary health insurance during their stay abroad if this insurance is provided as the only service in accordance with law (article 174 line 4, Law on Health Insurance). A travel health insurance contract has all the characteristics of an insurance contract. It is a nominate contract, a bipolar contract (it also includes business law and consumer law), an 
adhesion contract, an aleatory contract, a bilateral contract and an onerous contract, a formal contract and an intuitu personae contract. Innovations in travel health insurance contracts are significantly less than innovations in life insurance contracts, which for the most part are derivatives of the traditional contract to achieve adaptability to the individual needs of customers of insurance (Ćurak, 2004). Travel insurance is a generic term used to encompass various insurance coverages available to a business and leisure traveller. These include medical expenses and evacuation, cancellation or curtailment of the trip, and loss or theft of personal possessions. Two broad types of insurance sold are trip policies, which are issued for a specific trip or vacation and generally specify a duration in days, and annual policies, which will cover all trips within a year, subject to certain restrictions (Brusky, 2004). Keeping in mind the limited scope of this paper, the travel health insurance contract's most essential legal characteristics will be processed in the article without going into the general provisions of the insurance contract law. This article could be considered a contribution to the research because this form of insurance contract receives insufficient publicity.

A policyholder is any person or entity paying the premium and expressing the interest to enter into the insurance agreement with the insurer (Article 1, line 1, Terms and conditions of travel health insurance of Dunav Insurance Company, applied as of 17 September 2020) ${ }^{2}$. The insured is a person specified in the insurance agreement or schedule to whom the insurance premium has been paid and who is entitled under the insurance agreement to particular services and reimbursement of expenses in case of the occurrence of the insured event (Article 1, line 2, Terms and conditions of travel health insurance of Dunav Insurance Company, applied as of 17 September 2020). Under the terms and conditions of insurance companies in Serbia, the insured may be the person who is a citizen of the Republic of Serbia or a foreign national or a stateless person, provided that such person is a resident, i.e. holds the permission to temporarily or permanently reside in the Republic of Serbia. Under the Terms and Conditions of travel health insurance of Dunav Insurance Company, insured may be the persons of up to 85 years of age (Article 2, line 2, Terms and conditions of travel health insurance of Dunav Insurance Company, applied as of 17 September 2020), in Article 3 line 1 of General conditions of insurance of persons during their travel and stay in a foreign country of Wiener Städtische insurance

\footnotetext{
${ }^{2}$ Note: This article mostly analyses the Terms and conditions of the travel health insurance of the Dunav Insurance Company.
} 
company, applied as of 1 February 2020, the insured may be the persons from 3 months up to 83 years of age, and finally according to Article 2 of General conditions of insurance of persons during their travel and stay in a foreign country of Sava insurance company, applied as of 17 October 2019, the insured may be healthy persons regardless of age. A recent case showed that insurance companies refused to issue a travel health insurance policy to a 38-year-old pregnant woman, i.e. a travel insurance policy is also issued to pregnant women over the age of 38 , but warned that pregnancy and childbirth costs are excluded, except in the case of serious complications that endanger the life of the mother or child.

If the insurance agreement includes more than one person, any person shall have the capacity of the insured if for such a person insurance premium is paid and if he/she is specified in the insurance agreement or schedule of the insured which is an integral part thereof (Article 2, line, Terms and conditions of travel health insurance of Dunav Insurance Company, applied as of 17 September 2020). In case the insured is a foreign national, such insured cannot exercise rights under the travel health insurance agreement, either on the territory of the Republic of Serbia or the territory of the country of his/her residence and/or in which such insured receives corresponding health care (Article 2, line 6, Terms and conditions of travel health insurance of Dunav Insurance Company, applied as of 17 September 2020).

The insurance may be concluded as individual, group or family insurance. It is essential to point out that an insurance agreement must be concluded before travel to a foreign country. The policyholder is obliged to pay the premium in advance, in full and before the start of the insurance period, unless otherwise agreed. ${ }^{3}$ The insured or the policyholder shall be liable to pay the increased insurance premium in all cases of special contracting stipulated in the terms and conditions (Article 11, line 3, Terms and conditions of travel health insurance of Dunav Insurance Company, applied

\footnotetext{
${ }^{3}$ High prices of travel health insurance often prevent people with disabilities from travelling because policies are sometimes more expensive than plane tickets.
} 
as of 17 September 2020). ${ }^{4}$ For the agreed insurance cover, the insured event shall mean urgent and medically justified health assistance provided to the insured in a foreign country in order to avoid a life-threatening condition of the insured, i.e. to avoid his/her condition resulting in a permanent and considerable impairment of his/her health due to a sudden illness or injury (emergency), the expenses of which should be settled (Article 4, line 1, Terms and conditions of travel health insurance of Dunav Insurance Company, applied as of 17 September 2020). The authorised doctor must diagnose the illness or injury as a sudden and unexpected illness, infectious disease, organic disorder or injury which has occurred for the first time during the agreed insurance period and for which urgent medical assistance is medically justified. If the illness or injury has occurred prior to the beginning of the insurance agreement ${ }^{5}$ and its treatment continues even after the beginning of the insurance cover, the insurer shall not be liable to bear the incurred expenses unless medical assistance sought abroad includes unforeseen urgent measures taken for saving life or measures taken solely to relieve acute pains (Article 4, line 2 , Terms and conditions of travel health insurance of Dunav Insurance Company, applied as of 17 September 2020). At the conclusion of the insurance agreement, the insured or the policyholder shall be obliged to report or specify the purpose of the travel and provide any other

\footnotetext{
${ }^{4}$ Travel insurance policies were universally more expensive for people with diabetes; however, we found inconsistencies among insurance companies, with substantially increased premiums for people treated with insulin. Increases for non-insulin treated diabetes mellitus were relatively modest but varied considerably. Compared to those free of the disease, travel insurance costs were generally more expensive for adults diagnosed with type 2 diabetes mellitus (Angelopoulou et al., 2019). There is an urgent need for specialist to work with insurance companies to develop appropriate and realistically priced travel insurance for this patient group based on real-world data (Pickup et al., 2016).

${ }^{5}$ According to a new study conducted by the brokerage firm Medical Travel Compared, 79 per cent of British passengers misunderstand the information that must be disclosed to the insurer when buying travel medical insurance. Any mistake or a willingness to receive a lower premium may explain not disclosing the exact health condition. As a result, in situations where it is discovered that vital evidence was intentionally concealed, insurance firms limit or refuse to pay compensation. According to insurance company experience, people with complicated health problems would rather speak with a professional about travel insurance than purchase a policy online. The advent of technology has resulted in a plethora of new opportunities. Various providers have devised insurance support platforms houses by providing coverage to people with health conditions due to technological advancements (Insurance Post, 2019).
} 
information $^{6}$ necessary for the insurance premium calculation and conclusion of insurance. Insurance agreement may be concluded with different levels of insurance coverage.

The agreed level of coverage may be either basic or extended coverage (VIP). Basic insurance coverage includes the risks covered under the travel health insurance, as follows:

1. necessary assistance services in connection with the arrangement of insured's medical treatment,

2. measures of urgent medical assistance,

3. transport to the medical institution or country of residence, and

4. services of travel and legal assistance (Article 4, line 5, Terms and conditions of travel health insurance of Dunav Insurance Company, applied as of 17 September 2020).

Extended insurance coverage (VIP) may be stipulated for all types of travel and includes basic cover and additional cover for the organisation and transportation expenses of minor children up to 15 years of age and one adult escort to the place of residence, maximum up to EUR 1,500, only in case when the insured, due to the occurrence of the insured event, is unable to attend to his/her children; the organisation and transportation expenses maximum up to the price of economy class ticket and accommodation expenses of up to EUR 75 per day and maximum for three days, which are necessary for the visit of one person in the event that the insured, due to the occurrence of the insured event, has to be hospitalised at least 10 days before the transport to the country of residence, and solely after the approval of the insured; the organisation and expenses of medications delivery maximum up to EUR 100, solely if the medical treatment of the insured requires the medications which cannot be obtained on the territory where the insured event has occurred, and if these medications are sold in the Republic of Serbia and if their administration is allowed on the territory where the insured event has occurred, and they have been prescribed by the authorised doctor. This is an example of how extended insurance coverage (VIP) is regulated in the Terms and conditions of travel health insurance of Dunav Insurance Company. However, the terms and conditions of other

\footnotetext{
${ }^{6}$ The fact that the insured person before departure had heart problems treatment does not automatically lead to the predictability of treatment for a new heart attack during the insured period (Reisekrankenversicherung/Unerwartet schwere Erkrankung /Vorhersehbarkeit einer Behandlung, 2010).
} 
insurance companies obtain for example search and rescue, urgent drug delivery and repatriation of other insured participants in the accident.

The liability of the insurer shall be excluded for:

- Costs that exceed reasonable and usual costs;

- Chronic diseases and the consequences of those diseases that existed or were known at the time of conclusion or inception of the insurance;

- Removal of physical handicaps and anomalies;

- About intentionally caused illnesses and accidents by the insured;

- Sports risks, including training or participation in competitions;

- Diseases and accidents caused by intentional injury, suicide and attempted suicide;

- Diseases and accidents resulting from war and similar events; and

- Costs in connection with the treatment of cancer (Ćurak \& Jakočević, 2007).

This list does not exhaust the possibility of insurance companies expanding the list of costs that are not covered by insurance. From the aforementioned, it follows that pre-contractual and contractual notification of the insured are important, which is regulated in detail by the Insurance Law (Articles 82-84). Provisions of the exclusion agreement must be clear, unambiguous and written in such a way as to be noticeable. When the circumstances for exclusion are met, there is no coverage of insurance (Glušac, 2019).

\section{Specifics of travel health insurance}

Travel and tourism have been changing drastically in recent decades. Cheaper flights, sharing economy, rise and fall of destinations, and a need for "alternative" forms of tourism are just a few aspects shaping modern travel behaviour (Sarman et al., 2019). Tourism is not a compact and homogeneous area of the economy. It combines issues dealt with different fields and branches of law (Nowotarska-Romaniak, 2016). Today, almost no market-oriented insurance institution has developed travel health insurance among voluntary health insurance. Its market activity is related to the dynamics of business and tourist trips of domestic insured persons abroad and foreign insured persons abroad. It can be contracted daily or annually and is therefore issued a daily or annual insurance policy (Ćurak et al., 2007). The insurance premium is symbolic concerning the coverage the insured receives during the insurance period. The significance of a travel health insurance contract from the aspect of the insurance company 
is too underestimated. The travel health insurance contract is treated as a one-off by the insurance companies because they are contracted in a standard form, the current need is realised, and it does not give importance due to the indemnity character. Most policyholders travel for summer and winter holidays, and a travel health insurance contract is logically renewed from year to year, which significantly affects the stability of the insurance portfolio. The significance of a travel health insurance contract from the point of view of society and the state is reflected in the safety of citizens; when travelling, they know that someone takes care of them (Šipovac, 2014). Conservatively, it is estimated that between $30-50 \%$ of travellers become ill or injured whilst travelling. ${ }^{7}$

With the advancement of technology, new innovative solutions have come, in the form of substituting the classic travel health insurance policies, i.e. in advance printed forms of strict records, popularly called "manual, paper travel health insurance policies" because they are filled in only manually (Marović et al., 2013). The development of computers and the Internet have influenced almost every aspect of human society (Glušac, 2016). Many insurance providers offer a variety of options for purchasing travel insurance online. $^{8}$ Travel insurance bought online helps both service providers and buyers; the experience adds value to consumers by lowering premiums, improving services, and allowing customers to communicate with service agents more quickly (Kim et al., 2007). Chu (2001) suggests that online travel insurance services enable customers to identify insurance at a reasonable premium in the shortest delivery time. A customer throughout the buying process often engages in numerous activities, such as information searches, terms negotiations, and ongoing process monitoring; the objective, of course, is landing a favourable deal with lower transaction costs. After completing the entry, the necessary data for creating the policy, and creating policies, the policy is "simply" printed on plain A4 paper. Today hard copy of the policy is not a condition for its

\footnotetext{
7 There are many different types of travel insurance fraud; individual to a group, opportunistic to organised, false policyholder claims, overbilling and overcharging by medical providers, and fraudulent medical billing by third parties (The fight against travel insurance fraud is on, 2020). One of the most common frauds can also take the form of medical institutions overbilling. Some go so far as to pass off cosmetic surgery abroad as legitimate medical emergencies in a bid to get money from insurers. The fraudsters may even be in an alliance with a local doctor to create a fraudulent claim for emergency medical cover (The General Insurance Association of Singapore (GIA), 2019).

${ }^{8}$ Web sites of insurance companies are not approachable for people who do not distinguish colours, so purchasing insurance over the Internet is difficult for these people.
} 
validity. Namely, the validity is indisputable; it can be checked at any time by calling the contact centre of the insurance company code, which is also purchased (Šipovac, 2019). The advantage of electronic business and making a travel health insurance policy, sending the policy to the contractor and paying the premium also electronically is considered an evolution "of manually completed classical policy forms travel health insurance and calculating the insurance premium by digitron" to today's, modern, digital travel health insurance policies "on one click". The term "click" refers to the complete issuance procedure of these policies, from the first contact with the client, the collection of data necessary for policymaking, policy contracting, policy delivery, policy collection, in case of damage and enforcing and resolving the claim. The term "click" is presented first through the exploitation in the field of travel health insurance, and then in all types of insurance, in cooperation with all "smart/digital" devices, while in today's understanding of modern society, the term "click" has been upgraded in the segment of policy payments and general insurance services for digital forms of money and cryptocurrencies (Tomić, 2018).

Blockchain technology is an algorithm that first appeared in 2009 as a technology on which the digital currency bitcoin rests. Blockchain is the latest catalyst for transformation with the potential to become the most significant digital trend in this and the coming decades. This technology has the potential to affect the entire chain of insurance processes data collection, risk analysis, price formation or amount of premiums, policy issuance, payment request processing, etc. (Piljan et al., 2018). The significance of this technology lies in the fact that it has enabled the achievement of consensus on the evolution of data in the open Internet network, allowing synchronisation of the digital distribution share book without the inclusion of a reliable intermediary. It is expected that the digitalisation of insurance activities through blockchain technologies significantly improve business processes, trust, relevance and secure exchange of confidential information between business partners. At the same time, smart contracts will save costs and time by optimising and automating the process (Tomić, 2018). Tremendous potential for development lies in the following claims that the blockchain payment infrastructure is faster and cheaper, especially abroad in clinics that provide travel insurance services (Pavlović, 2019). When a tourist has to make a medical claim while on vacation, the attending doctor would submit and receive information about the patient's medical history, policy coverage, and all other relevant details in real-time. Not only is the mechanism extremely confidential, but blockchain also allows for much more efficient 
interaction, making it a powerful proposition for the insurance industry (Marke, 2019).

\section{Impacts of COVID-19 on travel health insurance}

Travel insurance has become a hot topic, and selling travel packages that provide travel insurance services could be a way to resurrect the industry. Due to rising tourism levels across the world, the global travel insurance market is projected to be worth more than US $\$ 35$ billion by 2025 . As a result, the tourism industry has been given a boost to capitalise on the growing demand for insurance among travellers. However, we are in an increasingly unpredictable environment, with new problems such as extremism, Brexit, and changing US travel and medical restrictions affecting travel plans and insurance (Marke, 2019).

Before the COVID-19 pandemic, travellers were predominantly under- or uninsured for their travel. This problem will likely be exacerbated when international travel resumes. A range of factors may explain traveller underinsurance, including risk framing, perceived immunity due to destination familiarity, and travellers' (mis)understanding of the risks of the destination (Caponecchia \& Tan, 2019).

Recognising the market's needs, Serbian insurance companies have adapted the products for all travellers in the country and abroad. In this situation, a special supplement was made to the travel health insurance policy, created for everyone who decides to travel abroad. This insurance covers the cost of necessary medical services if the test is positive, including testing for COVID-19. In addition, if necessary, insurance includes assistance in transporting patients abroad and returning to the country. Finally, in the case of hospitalisation abroad, a fixed lump sum in cash is paid as financial assistance. Travel health insurance with coverage for COVID-19 can be arranged as individual, family or group, for a period of up to 30 days. It is contracted as a supplement to the basic policy and provides coverage of treatment costs and fixed amounts of compensation if hospitalisation caused by the COVID-19 disease is necessary. In case of hospitalisation, the money is paid to the clients' current account in the bank (DDOR, 2020).

Analysing the offers of several insurance companies, we conclude that this insurance does not cover:

- Preventive testing for COVID-19;

- The cost of staying in quarantine isolation; 
- The costs which, according to the health protocol of the country in which the insured resides, are borne by the health system from the moment the COVID-19 diagnosis is made;

- Medical expenses if the infection occurred in countries for which the Ministry of Foreign Affairs has issued a warning/recommendation to avoid travel.

Also, some countries (e.g. Singapore) have introduced mandatory travel insurance for short-term visitors for their COVID-19-related medical treatment and hospitalisation costs in Singapore, with a minimum coverage of S\$30,000 (Mandatory COVID-19 Travel Insurance, 2021). Another type of mandatory insurance is when visitors must buy an insurance policy, e.g. the Aruba Visitors Insurance is mandatory insurance that helps protect visitors against incurred medical and non-medical expenses if testing positive for COVID-19 during their stay in Aruba. Visitors can buy or use their travel or health insurance to supplement the Aruba Visitors Insurance, but not to replace it (Aruba Visitors Insurance, 2020).

Following the coronavirus as the most frequently repeated word, phrase extraction showed that travel insurance was the second most frequently repeated phrase. Following the COVID-19 experience, travellers who are not accustomed to anticipating potential emergencies and making contingency arrangements would most likely include travel insurance in their plans. As the global recession ends, sales of travel insurance are expected to rise. Travel agencies will alleviate travellers' concerns about long-term planning by providing them with reliable travel insurance options. Following the pandemic, the most straightforward factor in restoring tourism statistics could be travel insurance choices, which customers are increasingly being aware of (Uğur, \& Akbıyık, 2020).

When international travel resumes, the role of travel insurance will be more important than ever, along with further research on effective communication by insurers to consumers regarding product coverage, value and risk.

At the time of writing this paper, a passport certificate on the coronavirus vaccination for free travel within the European Union will be proposed to the European Parliament. It will be proposed on March 17 and, if adopted, will only apply to vaccines established by the European Medicines Agency (EMA). Mediterranean countries, which depend on tourism because it accounts for 20, 25 per cent of GDP, support this proposal the most. These 
are primarily Greece, Croatia, Italy, Spain, even Cyprus and Malta, which want their tourism to be twice as good this season as before, because there are significant losses for them, and it is crucial that as many people as possible to come.

The function of this certificate is to show whether the person vaccinated has a negative test or has recovered from COVID-19 and has antibodies. This will most likely not be listed in legal terms for another five to ten years. The certificate is primarily intended as a digital document to be shown on mobile devices. However, the draft law also provides for the possibility of printing it out. It is therefore essential that a barcode can be scanned in order to check its authenticity. The document should be available in both the native language and English. In addition to information about a possible coronavirus vaccination, the document should also contain current test results and information about a corona illness. Different interests of individual member states or data protection issues of the EU Parliament may cause delays in the legislative process. Functional implementation, which is handled by each member state separately, can also trigger issues. One reason is that some countries, including Germany, do not yet have the requisite data stored centrally. Medical issues are still unresolved. It is unclear, for example, how likely it is that people who have been vaccinated or healed could spread the virus (Was für den digitalen Impfpass spricht? 2021).

From a legal perspective, the concept of privileges or special rights for vaccinated people is difficult. It is about the realisation of fundamental rights and freedoms to which every citizen is entitled. For hazard prevention and infection protection, these rights are currently largely capped for all citizens - from the mask requirement to the closure of large parts of the retail trade to the many travel restrictions. In their decisions on this matter, the courts have based a large part of the measures on the reasons of the high value of health protection, However, thy have always emphasised that the legislator must constantly check the necessity and appropriateness of the measures. This discussion will become even more explosive with the introduction of the planned vaccination pass (Impfpriorisierung $\mathrm{zu}$ statisch, Corona-Impfpass, arbeitsrechtliche Impfpflicht? 2021). Keeping in mind aforementioned, it will be interesting to see how insurance companies will react to this and how they will regulate the travel health insurance of those passengers who have covid passports in the future. 


\section{Conclusion}

Travel health insurance protects in the event of a sudden illness and injury during a stay abroad. A travel health insurance contract is of great importance both for the individual and for insurance companies, funds, society and the state from a global perspective. During the journey, every fifth tourist becames ill. Considering that this type of insurance is mainly regulated in detail by the general terms and conditions in this paper, the general terms and conditions of Serbian insurance companies were analysed. It is imperative that following the Law on Insurance, precontractual and contractual notification of the insured is performed. This is because insurance companies prescribe different insurance coverage, exclusion from insurance and the amount of insurance. Even though travel health insurance is not mandatory when travelling abroad, its sales have increased, and most insurers have improved insurance conditions introduced new products and introduced the possibility of choosing the rate of the insured amount and premium. However, if travel health insurance would eventually be introduced as compulsory, there would be a reduction in the high costs of treatment abroad, harmonisation of insurance premium rates, control of issued policies and insurance coverage, prevention of health insurance abuses.

With the advancement of technology, travel insurance makes up a significant part of online insurance, i.e. when planning a trip, one often forgets about taking out insurance and concludes it at the last minute with minimal investment of time. It is for this reason essential to identify the factors that influence online travel insurance contracting. Existing procedures for selling insurance policies to consumers and servicing and managing claims can be streamlined and improved. Users and data owners may have faith in the data's validity and protection thanks to blockchain.

The goal of insurers in a pandemic is to preserve business stability, focusing on protecting policyholders, injured parties and employees. In some types of non-life insurance, the number of new insurance contracts is also declining due to emergency measures, including closing borders, banning or restricting the movement of the population, public gatherings, and trade in certain types of goods and services. This is primarily the case with travel insurance (especially travel health insurance), transport insurance (especially in international transport) and credit insurance. Insurers have resumed offering policies to new customers, providing cost protection elements related to COVID-19 treatment, making potential 
passengers feel more comfortable knowing they are covered. Due to the COVID-19 pandemic, numerous countries have made proof of valid international health insurance mandatory for foreigners. Otherwise, they are not allowed to enter the country.

As the pandemic progresses, insurers must learn to provide current and reliable information to their customers; they must be proactive and prepared for quick reactions and answers. To keep their clients' confidence, they must continue to interact with them in a productive working atmosphere. Anyone who likes to travel a lot, regardless of whether privately or professionally, and wants to protect themselves against high costs due to medical treatment abroad should therefore never go on vacation without travel health insurance. Every vacationer should take out a foreign travel health insurance covering a possible corona treatment and repatriation.

\section{References}

1. Angelopoulou, K., Leslie, W., McCombie, L., Lean, M. \& Hankey, C. (2019), Diabetes and travel insurance costs: let's talk about remission. Pract Diab, Vol. 36, No. 1, 20-21.

2. [Anon.] (2010). Reisekrankenversicherung/Unerwartet schwere Erkrankung/Vorhersehbarkeit einer Behandlung. ReiseRechts aktuell, Vol. 18, No. 4, 197-198.

3. Aruba Visitors Insurance, https://www.aruba.com/us/traveler-healthrequirements (1 March 2021).

4. Brusky, R. (2006). Travel insurance. Encyclopedia of Actuarial Science, John Wiley \& Sons, Ltd, New Jersey.

5. Caponecchia, C., Tan, D. (2019). Exploring the traveller underinsurance problem. Annals of Tourism Research, Vol. 76, 343-345.

6. Chu, R. (2001). What online Hong Kong travelers look for on airline/travel websites? International Journal of Hospitality Management, Vol. 20, No. 1, 95-100.

7. Ćurak, M, Jakovčević, D. (2007.). Osiguranje i rizici [=Insurance and risks]. RRIF, Zagreb. 
8. Ćurak, M. (2004.). Osiguravajuća društva u financijskoj strukturi [=Insurance companies in the financial structure]. Doctoral dissertation, University of Split, Faculty of Economics, Split.

9. General conditions of insurance of persons during their travel and stay in a foreign country of Wiener Städtische insurance company, applied as of 1 February 2020.

10. General conditions of insurance of persons during their travel and stay in a foreign country of Sava insurance company, applied as of 17 October 2019.

11. Glušac, D. (2016). Ethical and legal aspects of distance learning. Monography: Socio-IT aspects of e-learning (Spoleczno-informatyczne aspekty e-learningu): Andrzej Frycz Modrzewski Krakow University, 2139.

12. Glušac, D. (2019). Isključeni rizici iz pokrića u osiguranju života [=Excluded risks from coverage in life insurance], Sloboda pružanja usluga i pravna sigurnost: Faculty of Law in Kragujevac, 319-329.

13. Glušac, D. (2020). Isplata otkupne vrednosti polise [=Payment of the redemption value of the policy]. XXI vek-vek usluga $i$ Uslužnog prava: Faculty of Law in Kragujevac, 85-93.

14. Insurance Law ("Official Gazette of the Republic of Serbia", No. 139/2014)

15. Insurance Post, Providing access, http://tokoviosiguranja.edu.rs/wpcontent/uploads/2020/04/20-01_7.pdf (1 March 2021).

16. Impfpriorisierung $z u$ statisch, Corona-Impfpass, arbeitsrechtliche Impfpflicht? https://www.haufe.de/recht/weitere-rechtsgebiete/strafrechtoeffentl-recht/einfuehrung-eines-corona-immunitaetspasses-als-quasiimpfpflicht_204_515498.html (17 March 2021)

17. Kim, D. J., Kim, W. G., \& Han, J. S. (2007). A perceptual mapping of online travel agencies and preference attributes. Tourism Management, Vol. 28, No. 2, 591-603. 
18. Law of Contract and Torts ("Official Gazette of the SFR od Yugoslavia No. 29/1978; Amendments Nos: 39/1985, 45/1989, and 57/1989; final amendments in the Official Gazette of the FR of Yugoslavia, No. 31/1993")

19. Law on Health Insurance ("Official Gazette of the Republic of Serbia", No. 25/129)

20. Mandatory COVID-19 Travel Insurance, https://safetravel.ica.gov.sg/ health/travelinsurance (1 March 2021).

21. Marke, K., Blockchain and travel, https://www.itij.com/latest/longread/blockchain-and-travel\#author-1422 (1 March 2021).

22. Marović, B., Tepavac, R., Njegomir, V. (2013). Osiguranje ekonomski principi [=Insurance - economic principles]. PE Official Gazette, Belgrade

23. National Bank of Serbia, https://nbs.rs/sr/finansijske-institucije/ osiguranje/poslovanje/, (1 March 2021).

24. Nowotarska-Romaniak, B. (2016). Preferences and Motives of Consumer Behavior in the Process of Purchasing Travel Insurance. Ekonomiczne Problemy Turystyki, Vol. 36, No. 1, 133-139.

25. DDOR (2020). Obezbeđenje od COVID-19 u inostranstvu [=Security from COVID-19 abroad]. https://www.ddor.rs/stanovnistvo-proizvodi/ putno-osiguranje/ (1 March 2021).

26. Pavlović, B. (2018). Blockchain tehnologija u osiguranju - nove tendencije sa potencijalom većim od rudarenja Bitcoina [=Blockchain technology in insurance - new tendencies with greater potential than Bitcoin mining], Proceedings of the 29th "Susreti osigiravača $i$ reosiguravača", Sarajevo, 239-255.

27. Pickup, L., Bowater, S., Thorne, S., Clift, P., Hudsmith, L. (2016). Travel insurance in adult congenital heart diseasen - Do they declare their condition?. International journal of cardiology, 223, 316-317.

28. Piljan, T., Piljan, I., Cogoljević, D. (2018). Uticaj blockchain tehnologije na osiguranje [=The impact of blockchain technology on insurance]. Vojno delo, Vol. 70, No. 2, 360-373. 
29. Sarman, I., Curtale, R., Hajibaba, H. (2020). Drivers of Travel Insurance Purchase. Journal of Travel Research, Vol. 59, No. 3, 545-558.

30. Šipovac, Z. (2014). Ugovor o putnom zdravstvenom osiguranju [=Travel health insurance contract]. Srpska pravna misao, Vol. 47, No. 1, 285-305.

31. Šipovac, Z. (2019). Digitalna (r)evolucija u osiguranju Republike Srbije [Digital (r)evolution in insurance of the Republic of Serbia]. Proceedings of the 29th "Susreti osigiravača i reosiguravača", Sarajevo, 361-383.

32. Terms and conditions of travel health insurance of Dunav Insurance Company, applied as of 17 September 2020.

33. The fight against travel insurance fraud is on, https://www.itij.com/ latest/long-read/fight-against-travel-insurance-fraud (17 March 2021)

34. The General Insurance Association of Singapore (GIA), https://www.budgetdirect.com.sg/blog/news/up-to-\$10000-reward-toreport-car-travel-insurance-fraud (17 March 2021)

35. Tomić, K., (2018). Blockchain tehnologija, pametni ugovori i njihova implementacija $\mathrm{u}$ industriji osiguranja [=Blockchain technology, smart contracts and their implementation in the insurance industry], Proceedings of the conference "Pravo i praksa osiguranja-Izazovi, nove tehnologije $i$ korporativno upravljanje", Palić, 133-145.

36. Uğur, N. G., Akbiyık, A. (2020). Impacts of COVID-19 on global tourism industry: A cross-regional comparison. Tourism Management Perspectives, Vol. 36. https://doi.org/10.1016/j.tmp.2020.100744

37. Vojinović, Ž., Glavaš, J. (2019). The importance of insurance in tourism - premium income for the continuation of risk management. Tourism International Scientific Conference Vrnjačka Banja - TISC, Vol. 4, No. 1, 642-662.

38. Was für den digitalen Impfpass spricht, https://www.zdf.de/ nachrichten/politik/corona-eu-impfpass-rechte-100.html (17 March 2021) 